\title{
Nutrition knowledge, beliefs and dietary habits among elderly people in Nizwa, Oman: implications for policy
}

A. Al Riyami, ${ }^{7}$ S. Al Hadabi, ${ }^{2}$ M.A. Abd El Aty, ${ }^{1}$ H. Al Kharusi, ${ }^{1}$ M. Morsi ${ }^{7}$ and S. Jaju ${ }^{7}$

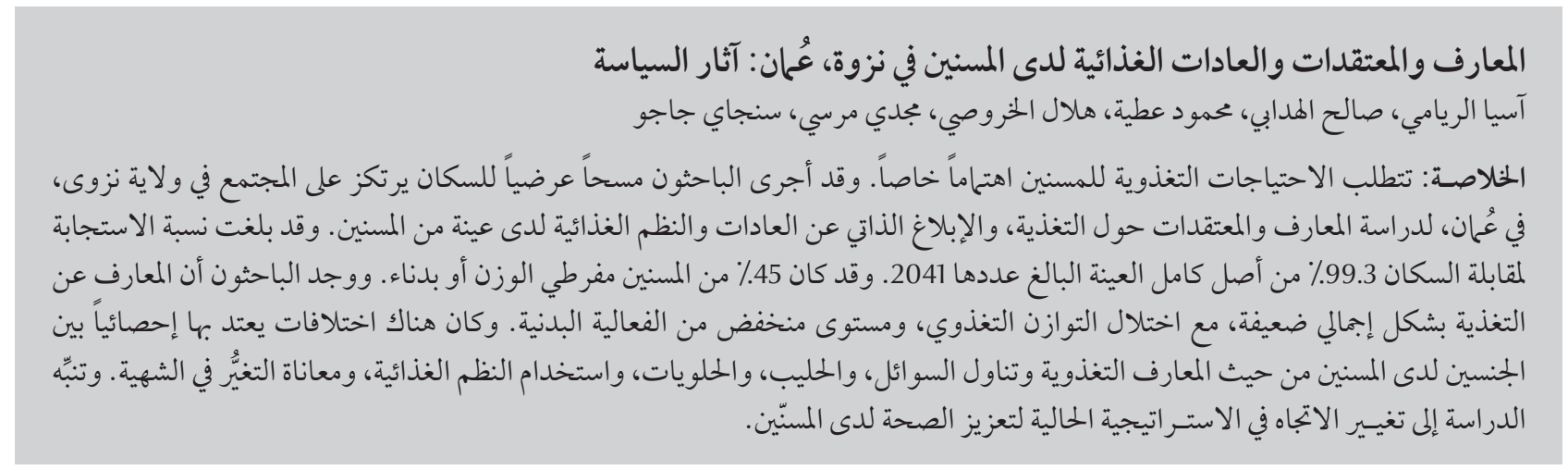

ABSTRACT The nutritional needs of the ageing population require special attention. We undertook a crosssectional, community-based, household survey in Nizwa wilayat, Oman to study nutrition-related knowledge and beliefs and self-reported dietary habits among a sample of elderly people. The response rate for the household interview was $99.3 \%$ from a total sample of 2041. About $45 \%$ of the elderly were overweight or obese. Overall we found poor knowledge of nutrition plus some nutritional imbalances and low levels of physical activity. Significant sex differences existed in elderly peoples' nutritional knowledge, consumption of fluids, milk and sweets, use of dietary regimens and experience of appetite change. The findings warrant reorientation of the existing health promotion strategy for the elderly.

\section{Connaissances et croyances en nutrition et habitudes alimentaires chez des personnes âgées à Nizwa (Oman) : répercussions sur les politiques}

RÉSUMÉ Une attention particulière doit être portée aux besoins nutritionnels de la population des personnes âgées. Nous avons réalisé une étude transversale communautaire auprès des ménages de la wilaya de Nizwa (Oman) afin d'étudier les connaissances et croyances en termes de nutrition et les habitudes alimentaires autodéclarées dans un échantillon de personnes âgées. Le taux de réponse des ménages à l'étude a été de 99,3 \% pour un échantillon total de 2041 sujets. Près de $45 \%$ des personnes âgées souffraient de surcharge pondérale ou d'obésité. Dans l'ensemble, les résultats montrent que les personnes âgées avaient de faibles connaissances en nutrition, qu'elles présentaient des déséquilibres alimentaires et qu'elles pratiquaient peu d'activité physique. Des différences significatives liées au sexe ont été observées en termes de connaissances en nutrition, de consommation de liquides, lait et sucreries, de recours aux régimes alimentaires et d'antécédents de modifications de l'appétit. Les résultats justifient une réorientation de la stratégie existante de promotion de la santé destinée aux personnes âgées.

'Directorate of Research and Studies, Directorate General of Planning, Ministry of Health, Muscat, Oman (Correspondence to A. Al Riyami: asyariyami@gmail.com).

${ }^{2}$ Directorate of Health Services, Al Dakhliya Region, Nizwa, Oman.

Received: 28/10/08; accepted: 12/01/09 


\section{Introduction}

The World Health Organization (WHO) has acknowledged that ageing and nutrition is a growing global challenge [1]. Modifying lifestyle factors such as diet can prevent, slow or reverse the onset of many of the chronic diseases associated with ageing. Identifying dietary patterns and specific dietary components that offer protection against chronic disease is important [2]. Perceptions of healthy eating and food group consumption practices of elderly men are largely unexplored [3].

The Food Habits in Later Life project of the International Union of Nutritional Sciences highlighted the value of rapid assessment procedures for developing food-based dietary guidelines for their aged members [4]. Elderly patients with a compromised nutritional status increase the burden on the existing health care infrastructure. The inpatient burden of elderly people in Oman is around 10\% [5].

This study was undertaken to assess nutrition-related knowledge and beliefs and self-reported dietary habits among a sample of elderly Omanis and to determine sex differences in their responses. It was hoped that the findings would be utilized for developing health promotion policy.

\section{Methods}

A cross-sectional, community-based, household survey of the profile and needs of non-institutionalized elderly Omanis aged 60 years and above was conducted in the Nizwa wilayat, Al Dakhliya region of Oman in 2005.

\section{Sample}

Our sampling frame was the 2003 census data [6]. The Ministry of National Economy provided a list of households where elderly people were resident, together with the corresponding enumeration area maps for the Nizwa wilayat.
Supervisors were involved in updating the maps and numbering the houses. The elderly who had moved to a different location in the wilayat and were residing in houses newly built since the census were also traced and recruited. Inhabitants of Jabal Akhdar and remote scattered houses were excluded due to logistic constraints. After updating the list of elderly people we found a total of 1508 houses inhabited by elderly people, which yielded 2041 elderly people. The response rate for the household interview was $99.3 \%(n=2027)$, while for the clinical examination and investigation it was $80.8 \%(n=1650)$.

\section{Data collection}

After approval by the research ethics committee of the Ministry of Health, Oman, informed consent was obtained from the participants. A structured questionnaire to assess 9 different domains of health relevant to the elderly in Oman was constructed, based on a literature review and expert opinion; only the nutrition domain is reported in this paper. The data were collected by personal interviews at home. The interviewers were health educators from the Ministry of Health and volunteers from community support groups who received 6 days of standardized intensive training. A second questionnaire to collect data from clinical examinations and investigations was completed by a medical doctor in the Nizwa community research centre. After the pilot study, data collection was conducted between June and August 2005.

The questionnaire collected basic demographic data about respondents: age, sex, marital status, education, occupation, personal income and whether living with their family. The next section assessed respondents' knowledge and beliefs about nutrition: whether the quality and quantity of food should change in older ages, what types of food to eat and whether certain food can protect or control diseases in later life. A section on dietary habits asked about number of meals eaten, whether their appetite had changed, the quantities of various food groups that they consumed and whether they consumed any special diets, took vitamin/mineral supplements, etc.

Currently there are no uniform food guidelines for the Arab region or portion size and food composition tables to suit the Arab food habits and culture [7]. For our nutrition analysis we took account of the traditional regional [8] and local dietary habits to establish appropriate frequencies of dietary intakes. In the questionnaire the responses were assessed as adequate/inadequate intake. Except for fluids, information about portion sizes was not collected. Adequate consumption of fish/meat/ chicken (animal proteins) was defined as consumption $>3$ times per week and inadequate as $\leq 3$ times per week. The same criteria were applied for vegetables, fruits and cereals. Intake of milk and milk products $\leq 3$ times per week was classified as less than adequate while 4+ times per week was adequate. Milk and milk products were classified as full-fat if 2 or more items out of milk, yoghurt and laban were reported to be full-fat. Information about portion sizes was not collected. Fluid consumption per day (water, milk, laban, fruit juices and other drinks) $\leq 1500 \mathrm{~mL}$ per day (measured by number of oral dehydration solution glasses) was considered inadequate.

We also assessed levels of physical activity based on daily chores and walking, with the cut-off set at 30 minutes exercise per day [9]. Body mass index was calculated and underweight, overweight and obesity were defined based on WHO criteria [10].

\section{Analysis}

Data entry was done in the region with Epi-Info, version 3.1, and data management and analysis was done using SPSS, version 9.0. Descriptive analysis of the nutrition-related data was done. Chi-squared tests of significance, with 
$P<0.05$ as significant, were used to assess sex differences for the relevant variables.

\section{Results}

\section{Background characteristics}

The sample of respondents consisted of $51.6 \%$ females and $48.4 \%$ males (Table 1). There were significantly more women in the 60-69 years age group (59.7\% of women, $53.8 \%$ of men) and fewer in the $70-79$ years group $(24.2 \%$ of women, $31.3 \%$ of men), while the sex distribution of the very elderly (age $80+$ years) was similar. A majority of participants resided in urban areas. The illiteracy rate among the women was $95.3 \%$, with only $3.9 \%$ having studied up to semi-primary level; the corresponding proportions for men were $67.6 \%$ and $25.8 \%$ respectively. Nearly $7 \%$ of men had primary level of education or above, compared with less than $1 \%$ of women $(P<0.001)$. Among men, $91.3 \%$ were married and $5.3 \%$ widowed compared with $45.1 \%$ and $48.7 \%$ respectively among women $(P<0.001)$.

Occupational status showed that $16.7 \%$ of elderly men were working while $98.9 \%$ of the women were housewives. Almost three-quarters of women $(72.0 \%)$ but only one-fifth of men $(20.8 \%)$ had no personal income. Overall $21.0 \%$ earned $<100$ Omani rials (OR) per month while $26.0 \%$ earned 100-199 OR. The difference in income levels between males and females was significant $(P<0.001)$. Almost all the men (97.3\%) had been resident with the same family for the previous 5 years compared with $93.8 \%$ of women $(P<0.001)$.

There was a higher rate of obesity in women (15.7\%) than men (10.5\%) $(P=0.02)$ and $31.5 \%$ of the total sample was overweight with $7.6 \%$ being underweight. Of the total, $49.4 \%$ were not physically active, while among the active respondents, more males were physically active than women $(21.6 \%$ of men versus $14.3 \%$ of women took $\geq 30$ min exercise/day $)(P<0.001)$.

\section{Nutrition knowledge and beliefs}

In the assessment of nutrition knowledge and beliefs (Table 2), $43.0 \%$ of the total sample believed that the quality of nutrition should change with age but only $17.2 \%$ believed that the quantity should change, with no significant difference between the sexes. Only 23.5\% accepted that they should include some specific types of food with advancing age, while about $26.7 \%$ were not certain about this. There was a significant sex difference on this issue, with a higher proportion of men giving affirmative answers. With respect to moderating the consumption of specific food types with age, significantly fewer women gave a negative reply than males, and more women were unsure $(P=0.022)$. However, a slightly higher proportion of women replied positively to the questions about the need to reduce the intake of sweets/sugar, fat and salt.

Respondents' detailed knowledge about the value of milk and dietary fibreswas quite poor, with $12.3 \%$ aware of the value of milk in protecting against osteoporosis while only $1.7 \%$ knew it as a rich source of calcium. There were significant sex differences, with fewer women than men having knowledge about milk for osteoporosis prevention $(10.1 \%$ versus $14.6 \%)$ and as a source of calcium ( $1.1 \%$ and $2.4 \%)$. Only $7.3 \%$ of the total had heard about dietary fibre and, of those, less than $3 \%$ knew its importance in daily diet. A majority of the elderly did not know which foods were rich in dietary fibre. Significantly fewer women than men (29.4\% versus $31.5 \%$ ) $(P=0.004)$ were aware that changes in dietary habits could help in prevention and control of health problems. Only $20.4 \%$ of the total sample were aware that this could help in hypertension and diabetes, while less than 5\% were knowledgeable about the role of dietary habits in other specific illnesses.

\section{Nutrition practices}

The practice of consuming 3 meals per day was reported by $91.4 \%$ of the respondents (Table 3). One-third of women (33.5\%) compared with $27.3 \%$ of men had noticed a change in their appetite $(P=0.003)$. The most common reason was sickness (17.7\%), although $12.5 \%$ said they had lost their appetite for no reason, with women mentioning these factors more than men. Taking medicines was attributed as a reason by $2.5 \%$ of the elderly.

Respondents' self-reported levels of consumption showed that only $16.4 \%$ consumed adequate amounts of milk and there was a significant difference between the sexes as regards consumption of milk and milk products, with significantly fewer women than men (14.1\% versus $18.8 \%)$ consuming adequate amounts $(P=0.004)$. Full-fat dairy products were the preference of $38.8 \%$ of the sample. Of the total respondents $59.0 \%$ consumed adequate amounts of fish/meat/chicken, $83.4 \%$ adequate amounts of cereals and $85.0 \%$ adequate amounts of fruits. Vegetable intake, however, was inadequate for $88.6 \%$ of the total. Proportionately more women did not consume any type of sweets $(P$ $=0.01$ ) but $58.4 \%$ of the total sample had a sweet intake 1-3 times a week. There was no sex difference in the adequacy of consumption of fish/meat/ chicken, cereals, vegetables or fruits.

One-fifth ofthesample(19.4\%) took additional salt in their diet and $9.3 \%$ took vitamin/mineral supplements. Women had significantly lower fluid intake per day $(P<0.001)$. More women followed a diet regimen $(P<0.001)$, with $14.0 \%$ having fat and cholesterol restriction and around $10 \%$ having salt and sugar restrictions. 


\begin{tabular}{|c|c|c|c|c|c|c|}
\hline \multirow[t]{2}{*}{ Characteristic } & \multicolumn{2}{|c|}{$\begin{array}{c}\text { Males } \\
(\boldsymbol{n}=\mathbf{9 8 2})\end{array}$} & \multicolumn{2}{|c|}{$\begin{array}{c}\text { Females } \\
(n=1045)\end{array}$} & \multirow{2}{*}{$\begin{array}{c}\text { Total } \\
\%\end{array}$} & \multirow[t]{2}{*}{$P$-value } \\
\hline & No. & $\%$ & No. & $\%$ & & \\
\hline \multicolumn{7}{|l|}{ Residence } \\
\hline Urban & 877 & 89.3 & 935 & 89.5 & 89.4 & \multirow[t]{2}{*}{$>0.05$} \\
\hline Rural & 105 & 10.7 & 110 & 10.5 & 10.6 & \\
\hline \multicolumn{7}{|l|}{ Age groups (years) } \\
\hline $60-69$ & 528 & 53.8 & 624 & 59.7 & 56.8 & \multirow[t]{4}{*}{0.005} \\
\hline $70-79$ & 307 & 31.3 & 253 & 24.2 & 27.6 & \\
\hline $80-89$ & 104 & 10.6 & 119 & 11.4 & 11.0 & \\
\hline$\geq 90$ & 43 & 4.4 & 49 & 4.7 & 4.5 & \\
\hline \multicolumn{7}{|l|}{ Education } \\
\hline Illiterate & 662 & 67.6 & 996 & 95.3 & 81.9 & \multirow[t]{3}{*}{$<0.001$} \\
\hline Semi primary & 253 & 25.8 & 41 & 3.9 & 14.5 & \\
\hline Primary \& above & 65 & 6.6 & 8 & 0.8 & 3.6 & \\
\hline \multicolumn{7}{|l|}{ Marital status } \\
\hline Never married & 14 & 1.4 & 13 & 1.2 & 1.3 & \multirow[t]{4}{*}{$<0.001$} \\
\hline Married & 896 & 91.3 & 471 & 45.1 & 67.5 & \\
\hline Widowed & 52 & 5.3 & 509 & 48.7 & 27.7 & \\
\hline Divorced & 19 & 1.9 & 52 & 5.0 & 3.5 & \\
\hline \multicolumn{7}{|l|}{ Work status } \\
\hline Working & 164 & 16.7 & 11 & 1.1 & 8.6 & \multirow[t]{3}{*}{$\mathrm{n} / \mathrm{a}$} \\
\hline Not working & 818 & 83.3 & 0 & 0.0 & 40.4 & \\
\hline Housewife & 0 & 0.0 & 1034 & 98.9 & 51.0 & \\
\hline \multicolumn{7}{|c|}{ Personal income (OR/month) } \\
\hline 0 & 204 & 20.8 & 752 & 72.0 & 47.2 & \multirow[t]{6}{*}{$<0.001$} \\
\hline$<100$ & 205 & 20.9 & 221 & 21.1 & 21.0 & \\
\hline 100-199 & 468 & 47.7 & 60 & 5.7 & 26.0 & \\
\hline 200-299 & 63 & 6.4 & 4 & 0.4 & 3.3 & \\
\hline 300-399 & 15 & 1.5 & 3 & 0.3 & 0.9 & \\
\hline $400+$ & 27 & 2.7 & 5 & 0.5 & 1.6 & \\
\hline \multicolumn{7}{|c|}{ Living with same family for last 5 years } \\
\hline Yes & 955 & 97.3 & 980 & 93.8 & 95.5 & \multirow[t]{2}{*}{$<0.001$} \\
\hline No & 27 & 2.7 & 65 & 6.2 & 4.5 & \\
\hline \multicolumn{7}{|l|}{$B M I^{a}$} \\
\hline Underweight & 55 & 7.8 & 53 & 7.4 & 7.6 & \multirow[t]{4}{*}{0.020} \\
\hline Normal & 358 & 50.7 & 325 & 45.1 & 47.9 & \\
\hline Overweight & 219 & 31.0 & 230 & 31.9 & 31.5 & \\
\hline Obese & 74 & 10.5 & 113 & 15.7 & 13.1 & \\
\hline \multicolumn{7}{|c|}{ Physical activity (min/day) } \\
\hline 0 & 435 & 44.3 & 567 & 54.3 & 49.4 & \multirow[t]{3}{*}{$<0.001$} \\
\hline$<30$ & 335 & 34.1 & 329 & 31.5 & 32.8 & \\
\hline$\geq 30$ & 212 & 21.6 & 149 & 14.3 & 17.8 & \\
\hline
\end{tabular}

${ }^{a}$ Some data missing.

$B M I=$ body mass index .

$O R=$ Omani rials.

$n / a=$ not applicable. 


\begin{tabular}{|c|c|c|c|c|c|c|}
\hline \multirow[t]{2}{*}{ Dietary knowledge/belief } & \multicolumn{2}{|c|}{ Males } & \multicolumn{2}{|c|}{ Females } & \multirow{2}{*}{$\begin{array}{c}\text { Total } \\
\%\end{array}$} & \multirow{2}{*}{$\begin{array}{c}P \text {-value } \\
\text { (males vs females) }\end{array}$} \\
\hline & No. & $\%$ & No. & $\%$ & & \\
\hline $\begin{array}{l}\text { Agree quality of nutrition should chang } \\
\text { with age }\end{array}$ & $424 / 966$ & 43.9 & $434 / 1030$ & 42.1 & 43.0 & 0.617 \\
\hline $\begin{array}{l}\text { Agree quantity of nutrition should chan } \\
\text { with age }\end{array}$ & $177 / 957$ & 18.5 & $163 / 1019$ & 16.0 & 17.2 & 0.216 \\
\hline Type offoods to eat at older ages & $(n=980)$ & & $(n=1043)$ & & & \\
\hline Certain types offood should be eaten & & & & & & $<0.001$ \\
\hline Yes & 248 & 25.3 & 228 & 21.9 & 23.5 & \\
\hline No & 511 & 52.1 & 496 & 47.6 & 49.8 & \\
\hline Don't know & 221 & 22.6 & 319 & 30.6 & 26.7 & \\
\hline \multicolumn{7}{|l|}{ Types offood to eat: } \\
\hline Vegetables & 107 & 10.9 & 113 & 10.8 & 10.9 & 0.952 \\
\hline Fruits & 77 & 7.9 & 75 & 7.2 & 7.5 & 0.570 \\
\hline Milk & 63 & 6.5 & 71 & 6.8 & 6.6 & 0.732 \\
\hline Water & 87 & 8.9 & 83 & 7.9 & 8.4 & 0.456 \\
\hline Moderation of diet at older ages & $(n=969)$ & & $(n=1031)$ & & & \\
\hline \multicolumn{7}{|l|}{ Certain types offood should be moderated } \\
\hline Yes & 387 & 39.9 & 428 & 41.5 & 40.8 & 0.022 \\
\hline No & 375 & 38.7 & 343 & 33.3 & 35.9 & \\
\hline Don't know & 207 & 21.4 & 260 & 25.2 & 23.4 & \\
\hline \multicolumn{7}{|l|}{ Types offood to moderate: } \\
\hline Protein & 37 & 3.8 & 33 & 3.2 & 3.5 & 0.453 \\
\hline Cereals/starch & 47 & 4.9 & 34 & 3.3 & 4.1 & 0.150 \\
\hline Sweets/sugar & 206 & 21.3 & 239 & 23.2 & 22.3 & 0.302 \\
\hline Fat & 210 & 21.7 & 238 & 23.1 & 22.4 & 0.449 \\
\hline Milk & 6 & 0.6 & 11 & 1.1 & 0.9 & 0.276 \\
\hline Eggs/liver/brain & 10 & 1.0 & 4 & 0.4 & 0.7 & 0.084 \\
\hline Salt & 115 & 11.9 & 182 & 17.7 & 14.9 & 0.000 \\
\hline Fruits/vegetables & 10 & 1.0 & 5 & 0.5 & 0.8 & 0.156 \\
\hline Water & 1 & 0.1 & 0 & 0.0 & 0.0 & 0.302 \\
\hline Benefits of milk at older ages & $(n=980)$ & & $(n=1043)$ & & & \\
\hline Rich in calcium & 24 & 2.4 & 11 & 1.1 & 1.7 & 0.016 \\
\hline Rich in vitamin D & 11 & 1.1 & 7 & 0.7 & 0.9 & 0.280 \\
\hline Offers protection from osteoporosis & 143 & 14.6 & 105 & 10.1 & 12.3 & 0.002 \\
\hline Rich in protein & 7 & 0.7 & 5 & 0.5 & 0.6 & 0.492 \\
\hline Helps to prevent constipation & 35 & 3.6 & 38 & 3.6 & 3.6 & 0.931 \\
\hline Benefits of dietary fibre at older ages & $(n=978)$ & & $(n=1042)$ & & & \\
\hline Heard about dietary fibre & 80 & 8.2 & 67 & 6.4 & 7.3 & 0.130 \\
\hline \multicolumn{7}{|l|}{ Benefits of dietary fibre: } \\
\hline Regulates intestinal movements & 36 & 3.7 & 28 & 2.7 & 3.2 & 0.203 \\
\hline Relieves constipation & 17 & 1.7 & 10 & 0.9 & 1.3 & \\
\hline Other uses & 27 & 2.8 & 26 & 2.5 & 2.6 & 0.709 \\
\hline \multicolumn{7}{|l|}{ Foods rich in dietary fibres: } \\
\hline Fruits & 14 & 1.4 & 11 & 1.0 & 1.2 & 0.445 \\
\hline Vegetables & 42 & 4.3 & 26 & 2.5 & 3.3 & 0.025 \\
\hline Whole cereals & 18 & 1.8 & 24 & 2.3 & 2.1 & 0.466 \\
\hline Plant proteins & 2 & 0.2 & 2 & 0.2 & 0.2 & 0.949 \\
\hline
\end{tabular}




\begin{tabular}{|c|c|c|c|c|c|c|}
\hline \multirow[t]{2}{*}{ Dietary knowledge/belief } & \multicolumn{2}{|c|}{ Males } & \multicolumn{2}{|c|}{ Females } & \multirow{2}{*}{$\begin{array}{c}\text { Total } \\
\%\end{array}$} & \multirow{2}{*}{$\begin{array}{c}P \text {-value } \\
\text { (males vs females) }\end{array}$} \\
\hline & No. & $\%$ & No. & $\%$ & & \\
\hline Changes in dietary habits at older ages & $(n=980)$ & & $(n=1043)$ & & & \\
\hline \multicolumn{7}{|l|}{$\begin{array}{l}\text { Changes in diet can protect and control } \\
\text { health problems }\end{array}$} \\
\hline Yes & 309 & 31.5 & 307 & 29.4 & 30.4 & 0.004 \\
\hline No & 355 & 36.2 & 328 & 31.4 & 33.8 & \\
\hline Don't know & 316 & 32.2 & 408 & 39.1 & 35.8 & \\
\hline \multicolumn{7}{|l|}{ Diseases that can be controlled by diet: } \\
\hline Hypertension & 194 & 19.8 & 218 & 20.9 & 20.4 & 0.537 \\
\hline Diabetes & 200 & 20.4 & 203 & 19.5 & 19.9 & 0.595 \\
\hline Hyperlipidaemia & 57 & 5.8 & 39 & 3.7 & 4.7 & 0.028 \\
\hline Coronary heart disease & 35 & 3.6 & 27 & 2.6 & 3.1 & 0.200 \\
\hline Obesity & 36 & 3.7 & 23 & 2.2 & 2.9 & 0.050 \\
\hline Anaemia & 13 & 1.3 & 10 & 0.9 & 1.1 & 0.436 \\
\hline Gastric/duodenal problems & 8 & 0.8 & 8 & 0.8 & 0.8 & 0.900 \\
\hline
\end{tabular}

\section{Discussion}

This was the first study of nutrition in the elderly conducted in Oman. The high illiteracy rate of respondents can be explained by the fact that all the respondents had reached adulthood before the country's recent renaissance which began in 1970, at a time when few Omanis had access to education. Females in the Arab world had less opportunity for formal education at that time and this accounts for the significant sex differences. The same was true for work opportunities and hence the income of the elderly respondents differed significantly between the sexes.

Changes in lifestyle and socioeconomic status have led to more sedentary lifestyles in Oman and levels of physical activity have decreased sharply in most Arab countries [11]. Half our overall sample took no physical activity and women spent significantly less time in physical activity than men, as most have domestic helpers for daily chores and there is little awareness of the value of walking as exercise. This, along with higher rates of multiparity [11], accounts for the higher prevalence of obesity in women than men (15.7\% versus $10.5 \%$ ).
Similar findings on obesity have been noted in elderly women in Egypt [8].

Although the proportion of females among the elderly is generally higher due to their higher survival rates, in this interior region of Al Dakhliya, we found a lower proportion of women in the 70-79 years age range and similar proportions in the $80+$ years age group. A possible reason could be unavailable or incorrect birth records, leading to misclassification of age in some cases. There are fewer cultural and social barriers to multiple marriage and remarriage by men, which accounts for a significantly higher proportion of men being married at the time of this study, while a higher percentage of women were widowed.

The elderly in our study lacked knowledge about the benefits of nutritional foods and a majority of men and women believed that there was no need to change the quantity and quality of nutrition with increasing age. A European study reported that $86 \%$ of elderly people believed that they did not need to change their eating habits as they already ate healthily [12]. However, researchers in Assuit governorate in Upper Egypt reported otherwise. They found that $44.0 \%$ of men and $63.4 \%$ of women in rural settings and
$77.3 \%$ and $63.8 \%$ respectively in urban settings believed that diet should differ with age, either decreasing the amount of food in general or restricting certain types of food [8].

Older people residing outside institutions eat reasonably well [13]. There is ample availability of foodstuff from different parts of the world in Oman. A majority of the elderly in this study lived with their family, and there is a tradition in Arab countries of caring for the elderly. Although there were significant differences between men and women in education and income level and the proportion living with their families, this was not reflected in differences in dietary intake of meat, cereals, fruits and sweets or in the frequency of meals per day Energy intakes fall with advancing age, but average protein intakes remain adequate [13]. High energy intake over decades leads to overweight in both sexes [14]. There is a shift in the Arab world from consuming traditional foods to more "fast-foods", which are characterized by high fat, cholesterol and sodium and low fibre [11]. A high proportion of our sample were overweight or obese. The impact of the promotional activities of the regional health care system and of the WHO Nizwa Healthy City project 


\begin{tabular}{|c|c|c|c|c|c|c|}
\hline \multirow[t]{3}{*}{ Dietary habit } & \multirow{2}{*}{\multicolumn{2}{|c|}{$\begin{array}{c}\text { Males } \\
(\boldsymbol{n}=\mathbf{9 8 2})\end{array}$}} & \multirow{2}{*}{\multicolumn{2}{|c|}{$\begin{array}{l}\text { Females } \\
(n=1045)\end{array}$}} & \multirow{3}{*}{$\begin{array}{c}\text { Total } \\
\%\end{array}$} & \multirow[t]{3}{*}{$P$-value } \\
\hline & & & & & & \\
\hline & No. & $\%$ & No. & $\%$ & & \\
\hline \multicolumn{7}{|l|}{ Meals eaten (per day) } \\
\hline 1 & 15 & 1.5 & 11 & 1.0 & 1.3 & NS \\
\hline 2 & 67 & 6.8 & 81 & 7.8 & 7.3 & \\
\hline 3 & 900 & 91.6 & 953 & 91.2 & 91.4 & \\
\hline \multicolumn{7}{|l|}{ Noticed change in appetite } \\
\hline Yes & 265 & 27.3 & 348 & 33.5 & 30.5 & 0.003 \\
\hline \multicolumn{7}{|l|}{ Reasons for change in appetite } \\
\hline Sickness & 147 & 15.1 & 209 & 20.1 & 17.7 & \\
\hline Taking medicine & 26 & 2.7 & 24 & 2.3 & 2.5 & \\
\hline Death of someone close & 3 & 0.3 & 13 & 1.3 & 0.8 & \\
\hline No apparent reason & 116 & 11.9 & 135 & 13.0 & 12.5 & \\
\hline \multicolumn{7}{|c|}{ Adequate consumption offoods(per week } \\
\hline Fish/meat/chicken & 559 & 58.4 & 611 & 59.6 & 59.0 & NS \\
\hline Cereals & 797 & 83.0 & 853 & 83.7 & 83.4 & NS \\
\hline Vegetables & 104 & 10.9 & 119 & 11.8 & 11.4 & NS \\
\hline Fruits & 810 & 83.7 & 885 & 86.2 & 85.0 & NS \\
\hline \multicolumn{7}{|c|}{ Consumption of sweets (times per week) } \\
\hline 0 & 315 & 38.4 & 393 & 44.6 & 41.6 & 0.01 \\
\hline $1-3$ & 506 & 61.6 & 489 & 55.4 & 58.4 & \\
\hline Consumption of extra salt in diet & 194 & 19.9 & 197 & 19.0 & 19.4 & NS \\
\hline \multicolumn{7}{|l|}{ Consumption offluids ${ }^{a}(m L$ per day) } \\
\hline Inadequate & 228 & 23.3 & 357 & 34.4 & 29.0 & $<0.001$ \\
\hline Adequate & 749 & 76.7 & 680 & 65.6 & 71.0 & \\
\hline \multicolumn{7}{|l|}{$\begin{array}{l}\text { Consumption of milk \& milk products } \\
\text { (times per week) }\end{array}$} \\
\hline Inadequate & 796 & 81.2 & 896 & 85.9 & 83.6 & 0.004 \\
\hline Adequate & 184 & 18.8 & 147 & 14.1 & 16.4 & \\
\hline \multicolumn{7}{|c|}{ Types of milk \& milk products consumed } \\
\hline Low fat/skimmed & 534 & 59.1 & 591 & 63.2 & 61.2 & NS \\
\hline Full fat & 370 & 40.9 & 344 & 36.8 & 38.8 & \\
\hline Take vitamin/mineral supplements & 83 & 8.6 & 104 & 10.0 & 9.3 & NS \\
\hline Follow diet regimen & 325 & 33.3 & 432 & 41.6 & 37.6 & $<0.001$ \\
\hline Restrict fat and cholesterol & 123 & 12.6 & 160 & 15.4 & 14.0 & \\
\hline Restrict sugar & 94 & 9.6 & 125 & 12.0 & 10.9 & \\
\hline Restrict salt & 84 & 8.6 & 130 & 12.5 & 10.6 & \\
\hline Eat more iron-containing foods & 6 & 0.6 & 0 & 0.0 & 0.3 & \\
\hline Eat more fibre & 7 & 0.7 & 7 & 0.7 & 0.7 & \\
\hline
\end{tabular}

Totals do not add up to sample size due to missing data; ${ }^{a}$ water, milk, laban, juices, other drinks; NS = not significant.

on nutrition seems to work positively only for the small proportion of the population who are aware of the health promotion programmes for hypertension and diabetes.

A high proportion of older adults in England had little basic nutrition knowledge and this was a barrier to healthier eating. Knowledge of associations between diet and diseases was particularly poor; $90 \%$ of subjects were unaware of the benefits of high fruit and vegetable consumption [15]. We found no sex differences in consumption of fruits and vegetables but the lack of knowledge related to fruits and vegetables was reflected in poor consumption of vegetables but not fruits in our study. We noted a significant sex difference for knowledge about the need to eat specific types of food, the need for moderation 
of certain types of food and whether changes in dietary habits can protect and control health problems at older ages. In another study men were found to have poorer knowledge about nutrition than women [16], whereas in our sample women had poorer knowledge. In a study related to fat intake from meat, meat products, dairy products and fried foods, women had higher nutrition knowledge scores and more negative views of fatty foods than did men [17]. More of our women had negative views about specific items such as sweets, fat and salt consumption. However, when it came to actual consumption, only sweets were significantly less frequently consumed by women, the other items being consumed equally by both sexes. Although women in our survey knew about the need to moderate their intake of fatty foods, they still consumed these foods, perhaps due to the existing belief systems and attitudes towards such food.

Nutritional knowledge about dairy products has been shown to be a better predictor of the type of milk consumed (e.g. lower fat milk to reduce fat intake) than the frequency of milk consumption [18]. We noted similar findings. Knowledge about the nutritional value of milk was very poor and women were less informed than men. Overall only $16.4 \%$ of the total sample, and significantly fewer women than men, consumed adequate amounts of milk. This shows the poor impact on this age group of the ongoing women's health programme in Oman. Among those who consumed milk products, $40 \%$ used full-fat milk and milk products, which again reflects traditional habits.

In the Ageing Nutrition project in Europe a comparative analysis of 36 studies showed that energy intake was too high, especially in some of the "younger old" and seemed not to be adjusted to the energy expenditure, whereas it was considerably lower than recommended in some very old seniors in some countries [19]. We cannot comment on the age difference, but energy intake was higher in our sample, which may be inferred from the number of meals per day, the adequacy of food consumption (meat, cereals, sweets and fruits) and the finding that only $7.5 \%$ of the total sample was underweight. The prevalence of obesity and overweight were also found to be higher than underweight in elderly men and women in Egypt [8]. In contrast to our findings, undernutrition in older people is considered to be a significant public health issue in the UK [20]. "Willingness to eat" plays a central role with regard to appetite among the elderly [21]. In our study decreased appetite noticed by the elderly people themselves was mainly attributed to unexplained factors and sometimes illness and use of medications.

Sex differences were found in food choices and energy and nutrient intakes in older British people, especially those aged 65-79 years [22]. Meal frequency has been found to increase in older people of both sexes, especially men [14]. Women have more regular consumption of fruits and vegetables [23], milk and diary products and vitamin supplements [14]. Almost all types of meat, eggs, and vegetables are preferred by men and their energy intake also tends to be higher. In both sexes, fat has been shown to represent a higher ratio of energy intake (39\%) than recommended [14]. In our study the dietary consumption patterns of men and women differed significantly only for milk and milk products, sweets and fluids, with women consuming less of these.

The major limitations of our study were that we did not use a validated questionnaire. Also we could not quantify the food consumption due to the unavailability of food consumption tables for Oman [24].

Intervention trials demonstrate that there are worthwhile health advantages for older people in changing their risk factors - e.g. weight reduction, sodium restriction, saturated fat reduction - to make their later years healthier, more active and more independent [25]. Effective intervention is required for improving knowledge among the elderly in our study. Dietary advice should be based on elderly women's food preferences and habitual foods [26]. It is important to inform the elderly about known relations between food and disease. This is especially important for women, who have higher levels of obesity.

The WHO Regional Office for the Eastern Mediterranean has addressed the issue of health of the elderly for over a decade and has identified a need for appropriate food and nutrition care for the elderly. However, a draft of the proposed model national policy for the elderly by EMRO does not explicitly mention the nutrition component [27]. Similarly, the recommendations of the Third Arab Conference on Nutrition 2007 resulted in the Abu Dhabi Declaration to Promote Healthy Nutrition in the Arab countries [7], but did not specifically address the growing global challenge of ageing and nutrition.

\section{Conclusions}

Our findings that nearly $45 \%$ of elderly people in Nizwa were overweight or obese, and had poor knowledge of nutrition, along with nutritional imbalances and low levels of physical activity, warrants reorientation of the existing health promotion strategy for the elderly. The significant sex differences in nutritional knowledge need to be addressed. The above findings need to be incorporated into the awareness and education programme of the national strategy for "Active ageing and self care" proposed by the Ministry of Health and the Ministry of Social Welfare. A further detailed study is necessary in order to prepare a micronutrient supplementation programme for vulnerable groups including the elderly. 


\section{References}

1. Nutrition for older persons. World Health Organization [website] (http://www.who.int/nutrition/topics/ageing/en/index. html, accessed 18 April 2010).

2. McKevith B. Diet and healthy aging. Journal of the British Menopause Society, 2005, 11(4):121-125.

3. Lengyel CO, Tate RB, Bayomi DJ. Food group consumption and self-rated diets of elderly community-dwelling Canadian men. The Manitoba follow-up study. Journal of Nutrition, Health and Aging, 2007, 11(1):8-13.

4. Wahlqvist ML, Wahlqvist ML. "Malnutrition" in the aged: the dietary assessment. Public Health Nutrition, 2002, 5(6A):911-913.

5. Annual health reports. MOH hospital inpatients morbidity according to age groups and disease category. Muscat, Oman, Ministry of Health, Oman, 2003-2007.

6. Census 2003. Muscat, Oman, Ministry of National Economy, 2003.

7. Abu Dhabi declaration to promote healthy nutrition in the Arab countries. Recommendations of the Third Arab Conference on $\mathrm{Nu}$ trition, Abu Dhabi-UAE, 4-6 December 2007. Abu Dhabi, Arab Center for Nutrition, Abu Dhabi Food Control Authority and Health Authority (http://www.acnut.com/images/stories/ pdf/2ea.pdf, accessed 18 April 2010).

8. Abd El Aty MA. Health profile of the geriatric group in Assuit governorate, Upper Egypt [PhD thesis]. Department of Public Health Faculty of Medicine, University of Assuit, Assuit, Egypt, 1990.

9. Recommended amount of physical activity. Global strategy on diet, physical activity and health. World Health Organization [website] (http://www.who.int/dietphysicalactivity/factsheet_re ommendations/en/index.html, accessed 18 April 2101).

10. WHO Expert Consultation. Appropriate body-mass index for Asian populations and its implications for policy and intervention strategies. Lancet, 2004, 363:157-163.

11. Musaiger AO. Overweight and obesity in the Eastern Mediterranean Region: can we control it? Eastern Mediterranean Health Journal, 2004, 10(6):789-793.

12. De Almeida MD et al Healthy eating in European elderly: concepts, barriers and benefits. Journal of Nutrition, Health and Aging, 2001, 5(4):217-219.

13. Wahlquist ML et al. Food habits in later life-an overview of key findings. Asia Pacific Journal of Clinical Nutrition, 1995, 4:1-11.

14. Rurik I. Nutritional differences between elderly men and women. Primary care evaluation in Hungary. Annals of Nutrition and Metabolism, 2006, 50(1):45-50.
15. Moynihan PJ et al. The nutrition knowledge of older adults living in sheltered housing accommodation. Journal of Human Nutrition and Dietetics, 2007, 20(5):446-458.

16. Baker AH, Wardle J. Sex differences in fruit and vegetable intake in older adults. Appetite, 2003, 40(3):269-275.

17. Shepherd R, Towler G. Nutrition knowledge, attitudes and fat intake: application of the theory of reasoned action. Journal of Human Nutrition and Dietetics, 2007, 20(3):170.

18. Elbon SM, Johnson MA, Fischer JG. Developing an instrument to measure the influence of knowledge, behaviours and attitudes on milk consumption patterns in older participants of a community wellness group: a pilot study. Journal of Nutrition for the Elderly, 1996, 15(4):21-37.

19. Lesser $\mathrm{S}$ et al. Nutritional situation of the elderly in Eastern/Baltic and Central/Western Europe-the Ageing Nutrition project. Annals of Nutrition and Metabolism, 2008, 52 (Suppl. 1):62-71.

20. Holmes $S$. What do we know about... nutrition and older people? Journal of Family Health Care, 2004, 14(6):153-155.

21. Wikby K, Fägerskiöld A. The willingness to eat. An investigation of appetite among elderly people. Scandinavian Journal of Caring Sciences, 2004, 18(2):120-127.

22. Bates CJ, Prentice A, Finch S. Gender differences in food and nutrient intakes and status indices from the National Diet and Nutrition Survey of people aged 65 years and over. European Journal of Clinical Nutrition, 1999, 53(9):694-699.

23. Larrieu $\mathrm{S}$ et al. Sociodemographic differences in dietary habits in a population-based sample of elderly subjects: the 3C study. Journal of Nutrition, Health and Aging, 2004, 8(6):497-502.

24. Domain 25: Nutrition. In: Seventh five-year plan for health development 2006-2010. The National Strategic Plan. Muscat, Oman, Ministry of Health, 2006 (http://www.moh.gov.om/fiveyear Plan/English/Part\%2001.pdf, accessed 18 April 2010).

25. Horwath CC. Nutrition and ageing. In: Mann JM, Truswell ST, eds. Essentials of human nutrition. New York, Oxford University Press, 1998:499-511.

26. Gustaffson K, Ekblad J, Sidenvall B. Older women and dietary advice: occurrence, comprehension and compliance. Journal of Human Nutrition and Dietetics, 2005, 18(6):421-422.

27. A strategy for active, healthy ageing and old age care in the Eastern Mediterranean Region 2006-2015. Annex three. Cairo, World Health Organization, 2006 (WHO-EM/HSG/030/ E/01.06/1000) 